\title{
A Career for Life Scientists in Management Consulting
}

\author{
Rodney W. Zemmel \\ McKinsey \& Company, Incorporated, New York, New York 10022 \\ Correspondence: rodney_zemmel@mckinsey.com
}

Compared with life sciences, management consulting is a relatively new field. Nonetheless, leading firms have assumed a central role in the global business economy and command increasing influence as advisors to corporations and organizations in the public and social sectors. Offering robust analysis, independent and expert perspectives, and-in the best cases - valuable creative input, these companies focus on helping clients to improve their performance or more effectively execute their mission.

Because the top firms tackle the most complex problems for the most successful organizations in the world, they attract top graduates. But the field is no longer the sole province of those with MBAs. In recent years, the profession has increasingly diversified and now actively recruits candidates with advanced degrees in a range of disciplines-including the life sciences.

Those who join the field will find many parallels between the consulting approach and scientific inquiry. As a result, life scientists have many of the intrinsic skills needed to thrive in the industry, which can offer an extraordinary breadth of assignments, global experience, and an accelerated way to learn. At leading firms, the intensive training and development offered can pave the way for partnership, in which consultants counsel senior executives as peers. Many of those who leave become entrepreneurs or join top organizations-sometimes their former clients-at a leadership level.

M anagement consulting took root in the 1920s, when James O. McKinsey, a University of Chicago management professor, launched a small business to provide financial and accounting advice to local companies. Understanding that financial data could be mined to improve business performance, he launched McKinsey \& Company in 1926.

It was less than a decade after World War I, three years before the Great Depression, and a time of profound change in the U.S. economy. Ambitious young men and women were leaving rural America in droves, as McKinsey himself did, to seek unfettered opportunity in cities. Small family businesses were giving way to corporations. The success of Henry Ford's assembly line fanned interest in specialization, changing the profile of industry and the professions. And everyone, it seemed, was growing giddy (if not rich) by speculating in the stock market.

Against this dynamic backdrop, James McKinsey saw that no one was expressly serving the needs of chief executives charged with leading the growing business enterprises. When he founded his management consulting firm, it was with the idea that it would provide

Editors: Kaaren Janssen and Richard Sever

Additional Perspectives on Career Options for Biomedical Scientists available at www.cshperspectives.org

Copyright (C) 2018 Cold Spring Harbor Laboratory Press; all rights reserved; doi: 10.1101/cshperspect.a032946

Cite this article as Cold Spring Harb Perspect Biol 2018;10:a032946 
R.W. Zemmel

analytically rigorous and independent advice to top management.

Although McKinsey had the initial idea that launched the management consulting field, it was really his protégé, the lawyer Marvin Bower, who shaped the industry. Called "the father of modern management consulting" by the Harvard Business School, Bower had served on bankruptcy committees, learning how to gut businesses and retain what remained of value for bondholders. When he joined McKinsey in 1933, he hoped to serve businesses more broadly, and indeed, he did. Bower is credited with shaping the vision and culture of McKinsey, and he ultimately had enormous influence on the consulting profession as a whole.

Some of Bower's best ideas were adapted from other fields. For example, the professional conduct that distinguished law and medicine led him to author a set of guiding principles that remain - in an adapted form-a touchstone even today. Of note, these include putting clients' interests first and maintaining high ethical standards. According to Bower's "one firm" concept, offices are encouraged to cooperate rather than to compete with one another. This principle remains a core feature of the firm and the basis for its international diversity and its opportunities for mobility and entrepreneurship.

Other innovations influenced the management consulting industry as well. One of the most significant involved recruiting - specifically, the determination to emphasize talent and intrinsic intellectual strengths over experience. This led the firm to "experiment" in the mid 1950s with hiring MBAs straight from business school. It is difficult to imagine the consequences if those early MBAs had failed. Instead, they flourished. And soon after, many other consulting firms were also mining business schools for talent.

In time, the drive to build a preeminent firm with exceptional talent led McKinsey to broaden its recruiting to candidates with advanced professional degrees, such as $\mathrm{PhDs}$, JDs, and MDs, as well as holders of non-MBA master's degrees. Again, McKinsey was a pioneer in this recruiting strategy, which other consulting firms soon adopted. As technology and globalization have made specialized knowledge more important to clients, McKinsey has continued to diversify. Today, more than half of its $\sim 8000$ consultants have non-MBA backgrounds. They include entrepreneurs, scientists, doctors, authors, athletes, and military officers, as well as "experienced hires" from many industries, and represent a mix of nationalities, expertise, and tenures.

With this polyglot consulting community, the firm solves many complex problems for the world's leading corporations_-in industries including energy, pharmaceuticals, telecommunications, healthcare, media, consumer goods, and banking. McKinsey also works with leading organizations in the public and social sectors and invests actively in pro bono efforts, serving 70 governments and four of the top five foundations in the world. At any given time, the firm's consultants might focus on issues ranging from helping hospitals decrease wait times for patients, cell phone manufacturers to partner with music companies, schools to increase graduation rates, and consumer companies to integrate postmerger.

Since the founding of management consulting more than 85 years ago, the field has grown exponentially. Some firms focus broadly on important issues facing CEOs and other senior executives. These include The Boston Consulting Group (BCG), Bain \& Company, and Booze \& Company. Still other consultancies serve businesses at different levels of the corporate structure. Such firms include Deloitte Consulting and Oliver Wyman, among others. The field has also expanded to include a myriad of smaller, "boutique" firms that specialize in a variety of industries and disciplines. They serve clients more narrowly on almost any topic one can think of-from helping airlines design their route systems to helping companies upgrade information technology used by salespeople.

Consulting firms have become a fixture in the world's business landscape. And their presence seems secure: As change continues to accelerate, as globalization expands, and as the private, public, and social sectors increasingly collaborate on the world's most pressing issues, 
the need for rigorous problem solving and expert, unbiased advice seems unlikely to diminish.

\section{JOBS}

Unlike corporate environments, management consulting, with its client and project focus, can open up a world of opportunity to explore different industries, functions, and geographies over time and to build expertise in one or several areas. The descriptions here reflect my own personal experience at McKinsey but include some features of other management consulting firms that generally have a narrower focus and client base.

Typically, the associate position is the most common point of entry-one that offers an exceptional growth experience. At McKinsey, for example, associates work on a variety of engagements within their first year and over time have tremendous flexibility to explore, specialize, change course, or do something new, depending on their preference. In the past five years, the firm has served several thousand clients with a wide range of projects in different industries and countries at any given time. Associates receive substantial training that is designed to help them to build leadership skills as well as the ability to lead their own client project areas. The training occurs both in formal settings and on the job, as part of the firm's apprenticeship model.

For example, before starting work, most advanced-degree holders attend a three-week
mini-MBA program. This follows a one-week training program that introduces the firm's approach to solving problems and communicating with clients. Many associates receive up to eight weeks of formal training within their first two years at the firm, which invests more in knowledge and capability building each year than do the leading business schools. The review processes focus as much on building individual strengths as on identifying development needs.

Learning that happens less formally is equally important. Because the firm works in teams and embraces an apprenticeship model, much development occurs in team rooms and client settings. Associates can expect to receive coaching from peers (who may have different strengths) and from engagement managers, who lead teams on a day-to-day basis. Associates also receive mentoring from associate principals (who apprentice as partners-in-training) and from partners themselves, who are responsible for the overall quality of the work and who counsel CEOs as peers. Because the firm has a culture of collaboration and a distinct way of working side by side with clients, much learning also occurs "organically" through interactions with clients. Successful associates can expect to be elected partner in roughly six years (see Fig. 1 for a description of various positions and an illustration of career progression).

Many client engagements begin with a kickoff meeting, in which teams discuss their aspirations for a client project, its scope, timing,

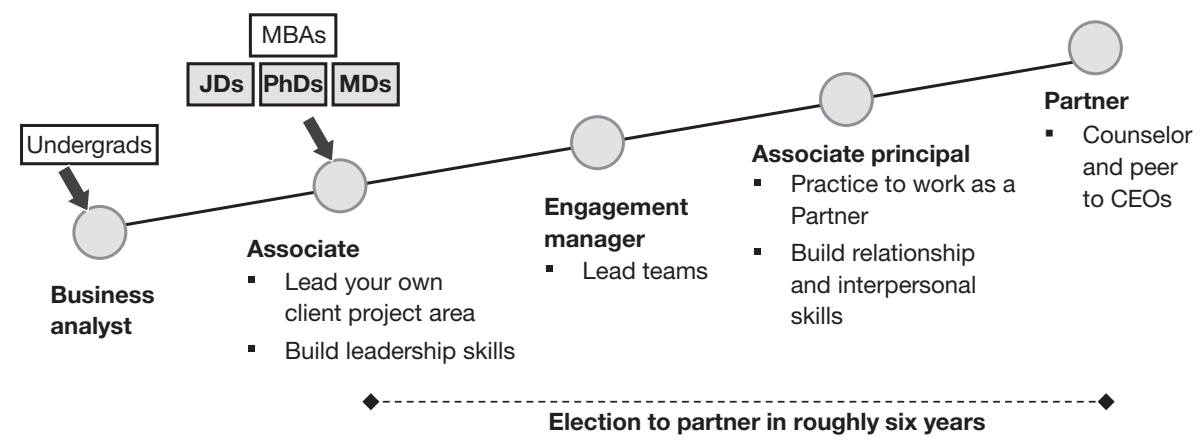

Figure 1. Career progression and related responsibilities. The example is specific to McKinsey, but may be generally applicable to other firms. 
R.W. Zemmel

"boundary constraints," sources of insight or expertise, as well as the development goals of each team member. The purpose is to ensure that the team exceeds client expectationsknocking it out of the park, if you will-while simultaneously providing a rich development experience for each team member. In addition to fostering collaboration, this system promotes intellectual freedom and egalitarianism.

In the meetings, teams often agree on a set of norms to guide their approach to work as well as to manage "work style" and lifestyle preferences. This includes planning in advance how the team will balance major project milestones and individual team members' outside obligations and interests.

\section{SKILLS/QUALIFICATIONS}

The top consulting firms seek candidates who have a strong record of achievement and leadership and who exhibit a capacity for continuous development. At the most basic level, consultants must have a strong intelligence quotient (IQ) and emotional quotient (EQ). They must have strong problem-solving capabilities to appropriately frame their client's issue, and then research and analyze data, synthesize findings, develop recommendations, and communicate these effectively.

But even with exceptionally smart solutions, nothing is gained unless the client supports the answer and is motivated to implement it - and can persuade scores of colleagues to go along. So consultants need a strong EQ as well, to be able to lead clients effectively and build trust-based relationships over time. At McKinsey, for example, more than $70 \%$ of the work occurs with clients with whom we have continuous relationships. In addition to requiring deep leadership skills, these trust-based relationships give consultants far greater latitude to achieve impact and to significantly improve client performance. Accordingly, recruiting processes are finely tuned to select people with the required capabilities. In reviewing applications, the firm looks for the following four characteristics:

1. Problem solving. An ideal candidate reasons logically and demonstrates curiosity, creativ- ity, good business judgment, a tolerance for ambiguity, and an intuitive feel for numbers.

2. Achievement. Candidates should set high aspirations, expect and achieve outstanding results, handle obstacles well, show signs of entrepreneurship, and have a willingness to take personal risks.

3. Personal impact. Candidates should be able to influence others in a positive way, show an interest in other people, demonstrate selfconfidence without arrogance, and listen, understand, and respond well to others.

4. Leadership. Candidates should be able to assume leadership roles, seize opportunities and take action, help build highly effective teams with a shared vision, and be sensitive to the thoughts and feelings of other team members.

Because management consulting and scientific inquiry have many parallels, life scientists have a number of assets that can make them strong candidates and help them to excel in the industry, including the following:

- Training. Consistent with the approach used by management consulting teams, life scientists use logic and analysis to develop hypotheses, and then find facts to prove or disprove them.

- Intellectual curiosity. Similar to many management consultants, life scientists are attracted to continuous learning. In their research, they look to answer problems that others have not been able to answer and to try solutions that others have not thought of.

- Credibility. In some consulting work, advanced degrees give life scientists enhanced credibility with clients and occasionally relevant content knowledge.

- Publishing. Both fields encourage professionals to publish internally and sometimes externally.

\section{GETTING A FOOT IN THE DOOR}

Life scientists contemplating a shift to management consulting should look for opportunities 


\section{BOX 1. My Experience}

Before I entered management consulting, I studied natural sciences at the University of Cambridge and stayed to earn a PhD in molecular biology. I enjoyed the subject, but I realized that I did not want to remain in academic research long term.

Although I loved the big-picture questions in science and the challenge of designing experiments, I found the average day to be less intellectually stimulating than I wanted it to be, given the repetitive nature of scientific inquiry. I also worried about the importance of serendipity, the relatively solitary nature of the field, and the difficulty of having a meaningful impact when $90 \%$ of the scientists who ever lived are working today — making any one person a very small part of a very large endeavor.

So I began talking to biotech companies and those in the life sciences industry and related fields, such as venture capital. More than once, I heard from these professionals that although they thought their own jobs were interesting, in their view, management consultants were doing the most exciting work. Consulting sounded like an extension of the learning experience, and more than that, it also offered an accelerated way to learn.

My initial plan was to join a management consultancy for a few years and then go into biotech, and I discussed that openly with interviewers. With that in mind, I joined McKinsey's London office in 1995. For the next few years, I worked on a wide range of projects-from a pro bono engagement aimed at combating youth homelessness, to studying electricity deregulation for a utility, to developing a growth strategy for a fast food chain. But eventually, I found my way back to healthcare and to pharmaceutical research and development (R\&D), which I was most passionate about. I was even lucky enough to serve a client that had licensed technology that I had worked on for my PhD (involving protein-RNA interactions in HIV). After approximately two years, I decided I wanted to see a different part of the world, and I moved to the United States. One of the nice things about a global firm such as McKinsey is that relocating is easy to do. Since I moved to New York, I have specialized in serving U.S. and global healthcare clients, which has taken me all over the worldfrom Brazil to India to Tokyo. I am now Managing Partner, Northeast office (New York, Boston, Stamford) for McKinsey \& Co.

One of things I have most enjoyed, and that was facilitated by the intellectual freedom of the workplace, has been helping to found our R\&D practice, within our healthcare practice. Together with like-minded people who also have a background in life sciences or medicine, I started to serve clients on R\&D productivity issues. This was a lot of fun and grew to become a significant part of our healthcare work. It also allowed us to stay close to the broader life sciences world, including its reputable journals. Some of our work has been published in Nature Reviews Drug Discovery and other leading journals.

Along with intellectual freedom comes the potential for a tremendous breadth of work. Within life sciences, I have had a chance to work on issues involving R\&D productivity, medical device launch diagnostics, personalized medicine, mergers and acquisition $(M \& A)$, organizational design, growth strategy, and other issues. I have also had an opportunity to move to the other side of healthcare and lead the Health Care Services Practice, which serves hospitals, healthcare systems, payers, pharmacy benefit managers, and the like, and which is an exciting and fast-growing component of what we do. As part of that, we have also had a significant role in helping the industry to prepare for U.S. healthcare reform, which has involved everything from thinking through how to improve operations in hospitals to considering how profit pools will shift—and what that means for companies-as well as how to help more people get access to insurance coverage.

Healthcare sits at the intersection of business, technology, clinical developments, and public policy, and consulting is one of the rare fields that provides a view into all of these domains. I feel very fortunate to have chosen to build a career here. 
R.W. Zemmel

\section{BOX 2. Some Lessons Learned}

In speaking with candidates who are considering the management consulting field, our recruiters and interviewers hear some questions frequently. Here are some responses to questions that I have gotten from candidates in the past. In this case, the interviewer was a McKinsey colleague.

\section{Q. What are the most important lessons that you have learned?}

A. Assuming the role of leader of McKinsey's New York and northeast offices recently has provided yet another perspective, reinforcing some themes and bringing others into full view. And one of the most exciting things to see up close is also one of the most established values of our firm: We are a talent organization. Across all industry and functional practices, we place huge importance on finding, developing, and mentoring the very best people. This is consistent at every tenure.

Another important lesson involves the consulting lifestyle. One thing everyone said about consulting is that we work really hard and that the travel burden is huge. It is true that we travel a lot, although that depends a bit on your client base. Still, I always thought that I would be okay with that early in my career, but not once I had children. Instead, I have found that I manage it quite well. My wife and I live happily on Manhattan's west side with three kids, and I have reasonably good control over my schedule. As I look at our clients, and other leaders in industry, I find that they are traveling just as much. Similarly, academics and scientists at leading institutions work just as hard. I do not believe that consultants work any harder than top people in these fields. Moreover, we have built increasing flexibility into our model. More than 1100 of our people have chosen to work part time, and 40 partners have been elected while working part time. The programs reflect different needs and can involve working fewer days a week, taking extended time off between engagements or job sharing.

These flexible programs reflect, in part, the great diversity of our people. And that is one of things I found most surprising as I entered this field. I thought that I would find a bunch of MBAs with firm handshakes and stiff shirts who read the The Wall Street Journa/ cover to cover everyday. Instead, there is a whole range of talented people in this profession, from PhDs and those with other advanced degrees, to journalists, entrepreneurs, and even people from the military. And there is incredible diversity in nationalities.

Q. What has surprised you about the management consulting field?

A. One surprise has been how careers in management consulting evolve over time. There is always something new. I rarely feel that I am considering the same question twice. For someone interested in "the life of the mind," it is a very rich field indeed.

\section{Q. What do you wish you had known earlier?}

A. Early on, it would have been great to have confidence that clear thinking, logic, and asking good questions could get you a long way. And another thing: It is not enough to solve the problem. You also have to understand the people with whom you are interacting, where they are coming from, and what it is going to take to change. It is important to think as much about how to get something done as what the right answer might be.

And that is an important difference in the work of a management consultant versus a scientist. You have to enjoy working with people and through others and helping your clients to become more successful. You also need a tolerance for ambiguity and an interest in business. And management consulting demands a different kind of creativity than the kind you need in a laboratory. So even though there are lots of similarities between the two fields, it is not for everyone.

\section{Q. What best equips people for a consulting career?}

A. Clear and analytical thinking, reasoning ability_not necessarily requiring a great facility with numbers - clarity of communication, an ability to understand and empathize with people, and taking initiative. 
Q. What will be the most important skills for management consultants in the future?

A. All of those capabilities and an ability to maintain a broad perspective while having an increasing depth of knowledge in a specific functional area.

Q. How could you have better prepared for a management consulting career?

A. Once I knew I was interested in management consulting, I started to read business books and newspapers, and I found that somewhat helpful_-but only somewhat. What is more helpful is talking with people who are in the profession or who have interacted with consultants.

Q. What do you look for in a candidate?

A. What excites me is meeting someone who has real passion and enthusiasm in addition to the intellectual skills. That gives you the confidence that they are going to bring a lot of leadership to what they do.

Q. If you were not in this career, what would you want to do?

A. I do not have a good answer to that. This is a great fit for me personally.

Q. What will you tell your children about choosing the right path?

A. Do what you are excited and passionate about. When that is the case, you will be good at what you do. And do something that has variety. That will ensure that you stay excited about it for the long term.

to test the waters. For example, McKinsey offers postgraduate candidates, including life scientists, opportunities for an insider's look at the field. Programs range from an 8-12-week paid internship, in which candidates join a McKinsey team and work on a client project, to opportunities to work on a client case for more than three days. MDs also have an opportunity to participate in a one-day seminar that introduces the healthcare practice and provides an opportunity to meet consultants and understand their work.

Internships or summer rotations are available at other management consulting firms as well. In addition, some universities have created internal consulting functions that serve industry. The University of Pennsylvania, for example, has a club that advises biotech companies. Some universities also offer business case competitions that are typically open to non-MBA candidates as well as students seeking advanced business degrees.

Candidates have many ways, outside of an academic or research setting, to demonstrate the skills that consulting firms value. For example, extracurricular activities can distinguish candi- dates. Activities that demonstrate leadershipin a laboratory, in the community, or on a sports team-can help to build a profile that attracts interviewers and recruiters. Entrepreneurial ventures, such as launching a nonprofit, can demonstrate a bent for innovation or emerging business skills. Similarly, excelling in team-oriented activities can signal a talent for developing relationships.

\section{WAY OUT}

Many consultants at top firms eventually leave the field to join industry (sometimes taking positions with clients whom they have served) or to become entrepreneurs. At McKinsey, which has been called "a leadership factory" by the business press, approximately one in five alumni start their own venture, and some 200 plus serve as CEOs of companies with revenues exceeding \$1 billion. Many others have gone on to hold distinguished leadership positions in public and social sectors.

McKinsey alumni with life sciences backgrounds have gone on to become senior executives of major healthcare, pharmaceutical, and 
R.W. Zemmel

biomedical research companies as well as financial services companies and investment firms, such as private equity and venture capital funds. Their positions range from $\mathrm{CEO}, \mathrm{COO}$, or chief medical officer to business development officer or managing director. Other life scientist alumni have gone on to start their own businesses, consultancies, or major foundations.

The top management consulting firms offer life scientists a chance to supercharge their careers, helping them to build strengths with some of the best training, mentoring, and apprenticeships available anywhere. Working across the private, public, and social sectors to serve some of the most successful organizations in the world, management consulting can allow life scientists a chance to discover new knowledge and capabilities as well as new passions. Whether joining the field for a few years or for an entire career, life scientists who make the move can find greatly expanded professional networks and opportunity. 


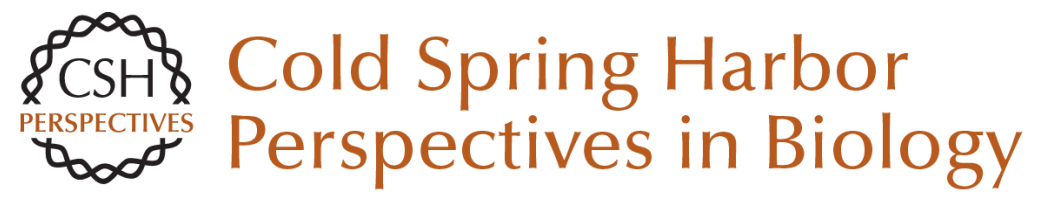

\section{A Career for Life Scientists in Management Consulting}

Rodney W. Zemmel

Cold Spring Harb Perspect Biol 2018; doi: 10.1101/cshperspect.a032946

\section{Subject Collection Career Options for Biomedical Scientists}

\section{Careers in Science Publishing} John R. Inglis

Medical Communications: The "Write" Career

Path for You? Yfke Hager

At the Crossroads of Science and Society: Careers in Science Policy Amy P. Patterson, Mary E. Groesch, Allan C. Shipp, et al.

A Career in Patent Law: At the Cutting Edge of Science, but Not at the Bench Salim Mamajiwalla

Careers in Science and Grant Administration: View from the National Institutes of Health Marion Zatz and Sherry Dupere

Careers at Biotech Start-Ups and in

Entrepreneurship Susan Froshauer

Careers in Science Journalism and Writing Helen Pearson

\author{
Careers in Academic Administration \\ Lydia Villa-Komaroff \\ Working for a Scientific Society \\ Martin Frank
A Career for Life Scientists in Management Consulting Rodney W. Zemmel \\ Careers in Core Facility Management \\ Claire M. Brown \\ Leaving the Bench and Finding Your Foundation \\ John E. Spiro
A Career at a Small Liberal Arts College Jennifer Punt \\ Career Options for Scientists \\ Richard Sever and Kaaren Janssen
}

For additional articles in this collection, see http://cshperspectives.cshlp.org/cgi/collection/

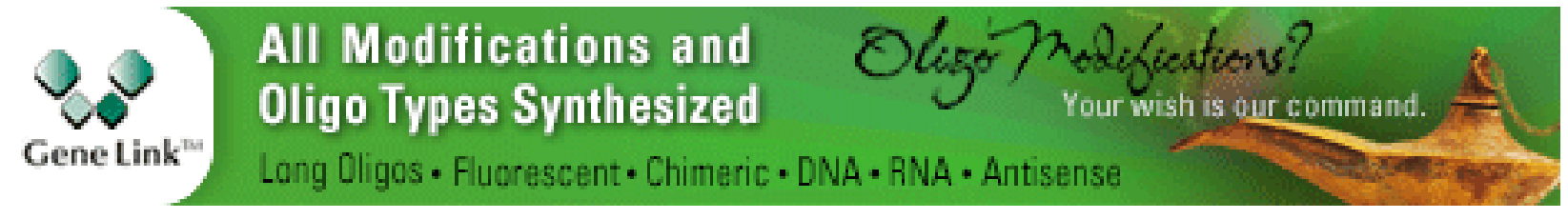

